\title{
PENANGGULANGAN ISU WIRAUSAHA DI INDONESIA DENGAN PEMBANGUNAN KOMUNITAS KRIYA JATINEGARA
}

\author{
Ruthy Elvana David ${ }^{1)}$, Lina Purnama ${ }^{2)}$ \\ 1) Program Studi S1 Arsitektur, Fakultas Teknik, Universitas Tarumanagara, ruthyelvanadavid@gmail.com \\ 2) Program Studi S1 Arsitektur, Fakultas Teknik, Universitas Tarumanagara, linapurnama.112@gmail.com
}

\begin{abstract}
Abstrak
Generasi Milenial adalah generasi yang lahir pada tahun 1981-1994. Generasi ini dikenal sebagai generasi yang open-minded, menyukai tantangan, berani mengambil resiko, memiliki pendirian yang kuat, dan tertarik untuk mencoba hal-hal baru. Ada fakta yang menyatakan bahwa sekitar 70,9\% Generasi Milenial tertarik untuk membuka usaha sendiri, sehingga banyak muncul istilah millennial entrepreneur, dimana mereka adalah wirausaha yang lahir di Generasi Milenial. Mereka mampu untuk menciptakan ide bisnis yang kreatif dan inovatif, yang berbeda dari yang lain. Walaupun tingkat wirausaha di Indonesia makin meningkat tiap tahunnya, tetapi sepertinya millennial entrepreneur di Indonesia belum dianggap oleh dunia karena jumlahnya hanyalah 1,65\% jika dibandingkan dengan negara lain (Singapura, Malaysia, Korea Selatan, Cina, Amerika Serikat, Thailand). Oleh karena itu, penulis bertujuan untuk meningkatkan jumlah wirausaha dengan memberikan wadah yang dapat menampung segala kegiatan mereka. Bukan hanya memberikan kegiatan pembelajaran, tetapi sampai ke kegiatan pokok mereka, antara lain; makan, mandi, olahraga, dan istirahat. Proyek ini, Komunitas Kriya Jatinegara, berlokasi di Jatinegara, Jakarta Timur. Metode yang digunakan dalam penelitian ini adalah metode cross-programming. Visi dari proyek ini adalah untuk menjadi bangunan multi-fungsi yang dapat memenuhi kebutuhan millennial entrepreneur. Selain itu, diharapkan proyek ini juga dapat menjawab isu kurangnya wirausaha di Indonesia dan isu sustainability. Sementara itu misi dari proyek ini adalah untuk menciptakan ruang yang dibutuhkan oleh Generasi Milenial sekarang ini, khususnya untuk wirausaha muda dalam mereka belajar (formal dan non-formal), bekerja, bersosialisasi, dan beristirahat.
\end{abstract}

Kata Kunci: Komunitas; Milenial; Multi-fungsi; Wirausaha

\begin{abstract}
Millennial Generation is the generation births from 1981-1994. This generation is known as a generation that is open-minded, like to challenge themselves, brave enough to take risks, determinded, and interested to try new things. There is a fact that says almost $70,9 \%$ of millennials are interested to start their own bussinesses. It is the reason of the term "millennial entrepreneur". That means an entrepreneur that is born in millennial generation. They have the ability to create creative and innovative bussiness plan that is different from others. Altough the number of entrepreneurs in Indonesia increasing every year, this has not been recognized by the worid because the amount is only 1,65\% of population compared to other countries (Singapore, Malaysia, South Korea, China, USA, Thailand). Therefore, the author aims to increase the number of entrepreneurs by providing a place that can accommodate all of their activities. Not only providing learning activities, but also their physical activities, such as: eat, take a bath, exercise, and take a rest. This project, known as Jatinegara Craft Community, is located in Jatinegara, East Jakarta. The method of this study is crossprogramming method. Vision of this project is to become a mixed-use building that can fulfill the needs of millennial entrepreneurs so that they can solve the issue of entrepreneurship in Indonesia and also the issue of sustainability. Meanwhile, the mission of this project is to create a place for the current millennial generation, especially for the young entrepreneurs in their study (formal and non-formal), work, social life and rest.
\end{abstract}

Keywords: Community; Entrepreneur; Millennials; Mixed-use 


\section{PENDAHULUAN}

Generasi Milenial adalah generasi yang lahir pada tahun 1981-1994. Generasi ini dikenal sebagai generasi yang menyukai tantangan dan tertarik untuk mencoba hal-hal baru. Dari sifat-sifat inilah muncul banyak Millennial Entrepreneur, dimana mereka adalah wirausaha yang lahir di Generasi Milenial dan menciptakan banyak ide baru yang kreatif dan inovatif dalam berbisnis. Namun nampaknya, millennial entrepreneur belum cukup berkembang di Indonesia.

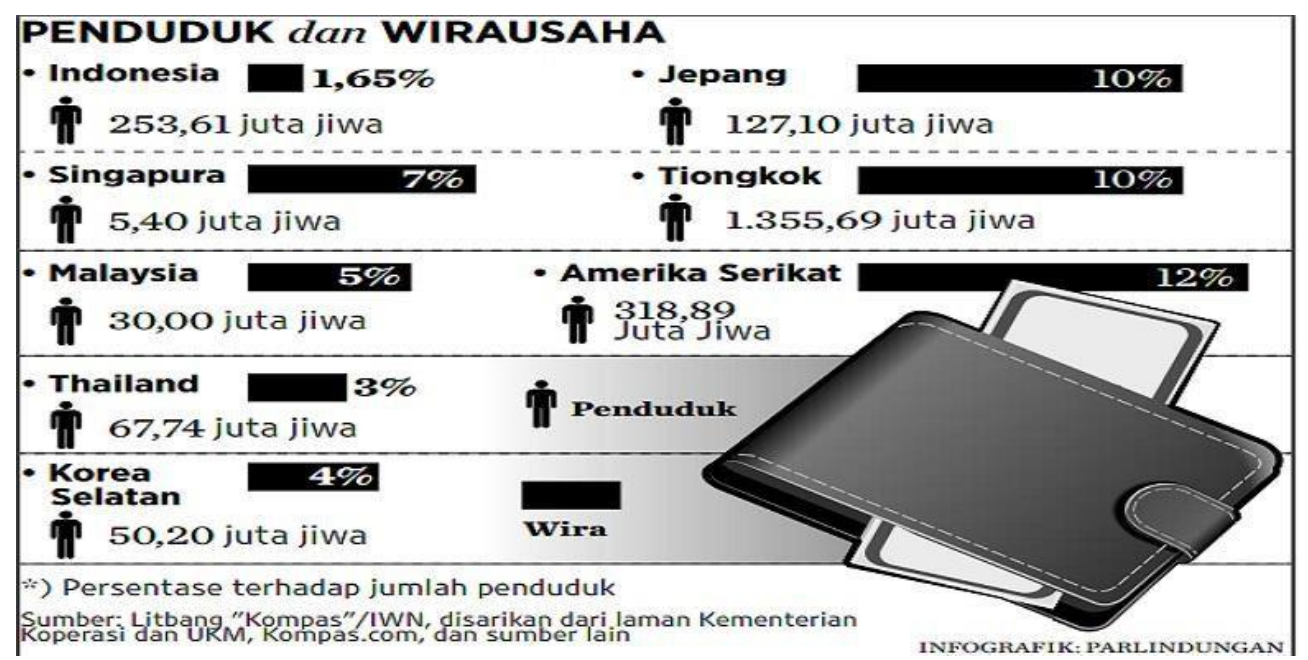

Gambar 1. Presentase Jumlah Wirausaha terhadap Jumlah Penduduk

Sumber: Kompas, 2017

Berdasarkan gambar diatas, Indonesia merupakan negara yang jumlah wirausahanya paling rendah dibandingkan dengan tujuh negara lainnya. Menurut penulis, salah satu penyebab paling krusial adalah karena kurangnya wadah untuk memberikan pelatihan atau menampung kegiatan para wirausaha. Oleh karena itu, terbentuklah ide untuk membuat sebuah bangunan mixed-use yang dapat memenuhi semua kegiatan para wirausaha, khususnya Generasi Milenial.

\section{KAJIAN LITERATUR}

\section{Milenial dan Perilaku}

Generasi Milenial seperti yang sudah dibahas sebelumnya, adalah generasi yang paling banyak dan terpelajar dibandingkan dengan generasi-generasi lainnya. Hal ini membuat Generasi Milenial berpengaruh sangat besar terhadap perkembangan di Indonesia, salah satunya adalah perkembangan di sektor ekonomi.

Perilaku Generasi Milenial antara lain adalah:

- Tidak suka bekerja di bawah tekanan.

Jumlah Generasi Milenial yang bekerja lebih sedikit dibandingkan dengan generasi-generasi sebelumnya. Hal ini dikarenakan mereka lebih mementingkan keseimbangan antara hidup dan bekerja sehingga jika mereka merasa tertekan di tempat kerja, mereka lebih memilih untuk berhenti bekerja daripada takut tidak mendapat gaji.

- Memiliki pendirian yang kuat, sangat tegas terhadap apa yang mereka mau.

Berdasarkan data dari consiouscompanymedia.com, hampir 65\% dari Generasi Milenial lebih memilih untuk mendapat gaji rendah terhadap pekerjaan yang mereka sukai dibandingkan dengan gaji yang lebih besar namun mereka tidak menyukai pekerjaan tersebut.

- Sekitar 70,9\% remaja ingin membuka usaha sendiri. Hal ini disebabkan karena sifat mereka yang suka kebebasan dan suka mencoba hal-hal yang baru. 


\section{Wirausaha}

Wirausaha atau entrepreneur adalah seorang yang memiliki kemampuan dalam menggunakan sumber daya untuk menghasilkan suatu produk, bisnis baru, produksi atau pengembangan organisasi usaha. Selain itu, wirausaha juga dapat didefinisikan sebagai orang yang dapat mengorganisasi, mengelola, dan berani untuk mengambil serta menanggung risiko dalam menciptakan usaha baru.

Menurut data tribunnews.com, rasio data wirausaha di Indonesia sudah meningkat menjadi 3,1\% dari 1,6\% pada tahun 2011. Namun walaupun demikian, peningkatan ini masih belum dianggap memuaskan di mata dunia. Berdasarkan Laporan The Global Entrepreneurship and Development Index 2017, Indonesia berada di peringkat ke-90 dari 137 negara dalam konteks kemampuan penduduk berwirausaha.

Dalam berwirausaha diperlukan beberapa faktor, salah satunya adalah kreativitas. Kreativitas jika tidak diterapkan dalam kewirausahaan dapat mengakibatkan performa wirausaha menurun dikarenakan perubahan zaman yang semakin cepat. Dari kreativitas ini munculah Ekonomi Kreatif.

\section{Ekonomi Kreatif dan Kontribusinya}

Ekonomi Kreatif merupakan sebuah aktivitas ekonomi yang terkait dengan menciptakan atau menggunakan pengetahuan informasi dan merupakan hasil dari kreativitas dan daya cipta setiap individu.

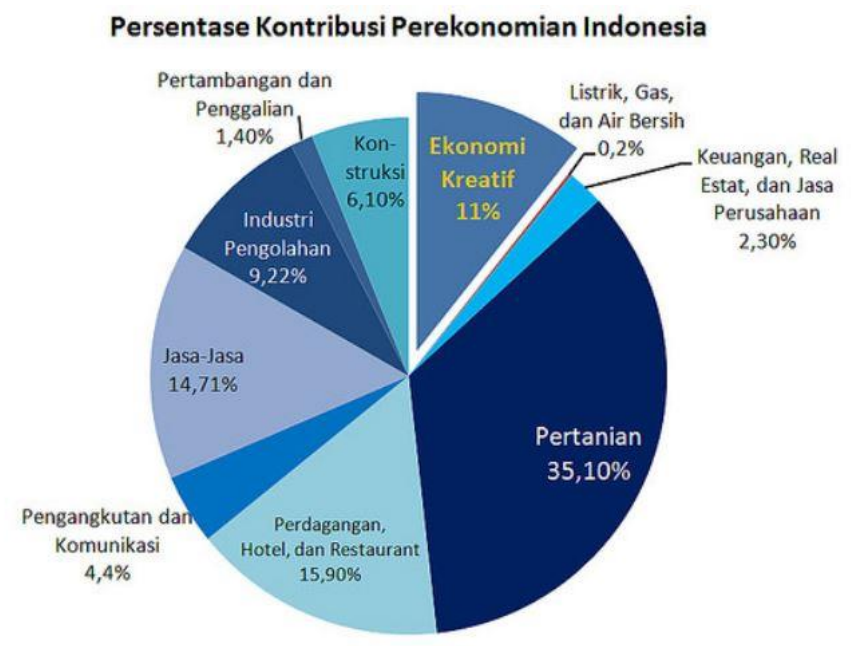

Diagram 1. Persentase Kontribusi Perekonomian Indonesia Sumber: Agribisnis, 2019

Dari diagram di atas, dapat dilihat bahwa Ekonomi Kreatif berpengaruh sebesar $11 \%$ dari 100\% kontribusi perekonomian Indonesia.

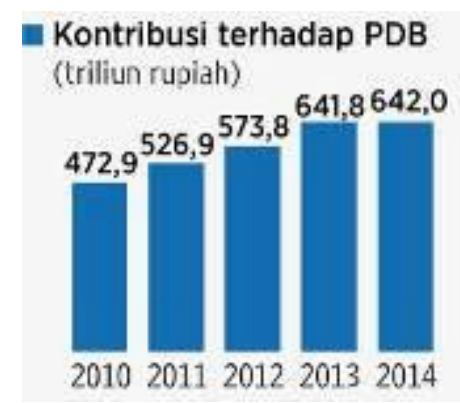

Diagram 2. Kontribusi Ekonomi Kreatif terhadap PDB (Produk Domestik Bruto Sumber: Batukarinfo, 2015 
Selain itu jika dilihat dari diagram batang di atas, dapat dilihat bahwa perkembangan ekonomi kreatif semakin meningkat setiap tahunnya. Ini menandakan bahwa ekonomi kreatif mulai diminati oleh masyarakat Indonesia. Namun pengembangan ekonomi kreatif masih belum dapat berkembang secara pesat dikarenakan masih minimnya wadah untuk menampung kegiatan ini.

\section{Makerspace, Sejarah, dan Tipe}

Dari makerspace.com, makerspace adalah sebuah tempat kerja kolaboratif yang biasanya berada di dalam sekolah, perpustakaan, atau fasilitas bangunan publik terpisah yang digunakan untuk membuat, mempelajari, mengeksplorasi dan saling berbagi ilmu tentang berbagai hal. Baik itu menggunakan teknologi ataupun tidak. Tempat ini terbuka bagi anakanak, dewasa, dan wirausaha. Biasanya tempat ini mempunyai berbagai macam alat, dari $3 D$ printer, laser cutters, bahkan sampai mesin jahit.

Pengertian lain mengenai makerspace adalah sebuah tempat fisik dimana banyak orang berkumpul untuk berbagi ilmu, bekerja dalam proyek, bersosialisasi, dan membuat sesuatu produk (Educase, 2013).

Makerspace sudah berkembang pesat, terutama di Amerika Serikat. Pembuatan makerspace yang dulunya di perpustakaan, sekarang juga diterapkan di sekolah-sekolah. Hal ini disebabkan atas permintaan Mantan Presiden Amerika Serikat, Barack Obama, dimana beliau menyatakan bahwa makerspace mempunyai potensi untuk diperkenalkan di sekolahsekolah.

Untuk membuat suatu makerspace, dibutuhkan adanya program ruang yang tepat sesuai dengan kebutuhan. Program ruang tersebut harus ditentukan dari beberapa hal, antara lain: tujuan dari makerspace itu sendiri, pemilihan tapak, dan target pengguna makerspace.

Sejarah Makerspace antara lain:

- Makerspace yang dibangun berdasarkan komunitas.

Dari buku yang berjudul Makerspace: Towards a New Civic Infrastructure, Holman berbicara mengenai sejarah makerspace yang dimulai dari Maryland Institure for Promotion of the Mechanic Arts, yang dibentuk oleh Benjamin Latrobe pada tahun 1826. Makerspace ini dibangun karena permintaan anggota dan mereka diwajibkan membayar tetapi dengan harga yang pantas.

- Makerspace yang berkembang berkat penemu terkenal.

Invention Factory (yang dibuat oleh Thomas Edison pada tahun 1876) dan Volta Laboratory (dibuat oleh Alexander Bell pada tahun 1877 yang jadi terkenal dengan Bell Labs). Kedua penemu ini berkolaborasi dengan inventor lainnya dan selalu memastikan makerspace mereka terfasilitasi dengan baik.

- Makerspace yang ditemukan oleh pemerintah sebagai laboratorium penelitian. 350 laboratorium penelitian dibuat di Amerika Serikat pada tahun 1900-1940 yang digunakan oleh pemerintah untuk menciptakan alat-alat perang pada saat perang dunia. Setelah Perang Dunia 2 selesai, laboratorium ini mendapat banyak permintaan.

- Makerspace yang mulai menggunakan mesin karena adanya perkembangan teknologi yang pesat.

Tech Model Railroad Club yang dibuat pada tahunn 1946 adalah makerspace pertama yang menggunakan mesin untuk dapat menjadi suatu produk baru. Contoh makerspace lainnya adalah Xerox Palo Alto Research Centre pada tahun 1960, di mana Steve Jobs dan Steve Wozniak pernah mengunjungi tempat ini di tahun 1979 sambil merancang komputer apple.

- Makerspace yang tidak terbuka untuk publik, melainkan untuk perusahaan dan universitas.

Menurut Will Holman, sekarang ini banyak tempat yang memutuskan untuk melakukan riset dan perkembangan teknologi ini secara kompetitif dan diam-diam. Selain itu, tempat 
ini juga membayar staff terpelajar untuk dapat mengajar sehingga dapat menghasilkan output dengan kualitas tinggi.

- Makerspace yang dibentuk untuk mengajar pengangguran.

Contoh makerspace ini dapat ditemukan di London pada akhir tahun 1980an, saat itu politikus tenaga kerja membuat lima jaringan teknologi yang masing-masing terdiri dari ruang workshop dimana para pengangguran mendapat akses untuk menggunakan mesin dan mendapatkan ilmu (Bozzonetti.2017).

Berikut ada beberapa tipe makerspace yang dikategorikan berdasarkan program ruang:

1. Community-Serving Makerspace

Makerspace ini menyediakan berbagai macam peralatan dan pelayanan yang bertujuan untuk membantu makers untuk dapat menghasilkan dan mengembangkan suatu produk. Pada makerspace ini presentase creation jauh lebih besar dibandingkan yang lain. Ini menunjukkan mereka lebih mementingkan esensi dalam menciptakan suatu produk dibandingkan esensi lainnya.

2. Industry-Serving Makerspace

Makerspace ini menyediakan co-working space dan berbagi peralatan untuk bisnis kecil berdasarkan jenis industrinya. Makerspace ini sifatnya lebih spesifik dalam satu jenis kerajinan dan lebih mementingkan perkembangan di satu kerajinan tersebut. contoh: industri kayu. Mereka lebih memilih untuk fokus ke kayu dan mengembangkannya menjadi produk dengan kualiitas dan ide dasar yang baik.

3. Makers Showroom and Support Center

Makerspace ini tidak akan menyediakan tempat studio (creation) melainkan akan menyediakan tempat retail, tempat konseling untuk mendukung bisnis, dan tempat coworking seperti kantor dan ruang seminar. Hal ini menunjukkan bahwa mereka lebih fokus ke esensi membuka bisnis dan menjualnya.

\section{Gaya Belajar dan Bekerja Generasi Milenial}

Menurut Sarah Landrum dalam artikelnya yang berjudul "5 Workspace Changes that Make Millennials Happy", ada lima elemen untuk dapat membuat Generasi Milenial dapat bekerja dengan baik;

- Coffee = Happiness

The National Coffee Association di Amerika Serikat melaporkan bahwa pangsa pasar dari pangan, terutama minuman kopi dibuat untuk Generasi Milenial. Hal ini yang menyebabkan berkembang pesatnya kedai kopi beberapa tahun terakhir ini.

- Soundproof

Kantor open space adalah kantor yang cocok untuk Generasi Milenial. Namun salah satu kekurangan dari kantor open space ini adalah sulitnya bagi mereka untuk dapat berkonsentrasi pada pekerjaan mereka. Biasanya bukan karena manusia yang ada di dalamnya tetapi bisa juga dikarenakan suara mesin, suara lift, atau suara lainnya dapat membuat mereka kehilangan konsentrasi. Dinding yang bersifat soundproof yang diletakkan di sekitar benda-benda demikian dapat membantu untuk mereka dapat fokus pada pekerjaan.

- Ergonomics

Ergonomi dalam tempat kerja merupakan hal yang penting, karena dengan kita mengaplikasikan ergonomi yang benar terhadap posisi duduk staf contohnya dapat meningkatkan akurasi, mengurangi rasa lelah, dan dapat menghemat waktu.

- Green Cleaning Practices

Pada tahun 1983, WHO (World Health Organization) telah menetapkan penyakit Sick Building Syundrome sebagai ancaman global. Penyakit itu antara lain iritasi kulit, 
kelelahan, sakit kepala, kehilangan fokus, dan gangguan pada mata, hidung, serta tenggorokan.

Penyakit ini dapat diatasi dengan melakukan Green Cleaning Practices, dimana kegiatan tersebut antara lain adalah melakukan daur ulang, menggunakan barang rendah energi, dan mengontrol kualitas air.

- Forest-bathing

Merupakan suatu terapi yang direkomendasikan oleh dokter-dokter di Jepang dengan tujuan untuk dapat meredakan stress dan depresi. Terapi ini dilakukan dengan membuat greenways di daerah kantor dan membawa shade-frendly plants ke dalam bangunan.

Untuk membuktikan hal ini, Universitas Harvard melakukan survei kepada 100.000 suster dan hasil dari survei ini membuktikan bahwa mereka mempunyai tingkat kematian lebih rendah $12 \%$ dibandingkan sebelumnya.

\section{METODE}

Metode yang digunakan pada desain ini adalah metode cross-programming, dimana metode ini menggabungkan berbagai program ke dalam satu proyek. Antara lain: program kategori komersial, edukasi, dan kehidupan sehari-hari.

\section{DISKUSI DAN HASIL}

Tahap-tahap yang dilakukan dalam merancang proyek ini pertama-tama adalah dengan menentukan lokasi perancangan. Untuk mendapatkan lokasi ini, dapat dilakukan dengan melakukan analisa makro kawasan.
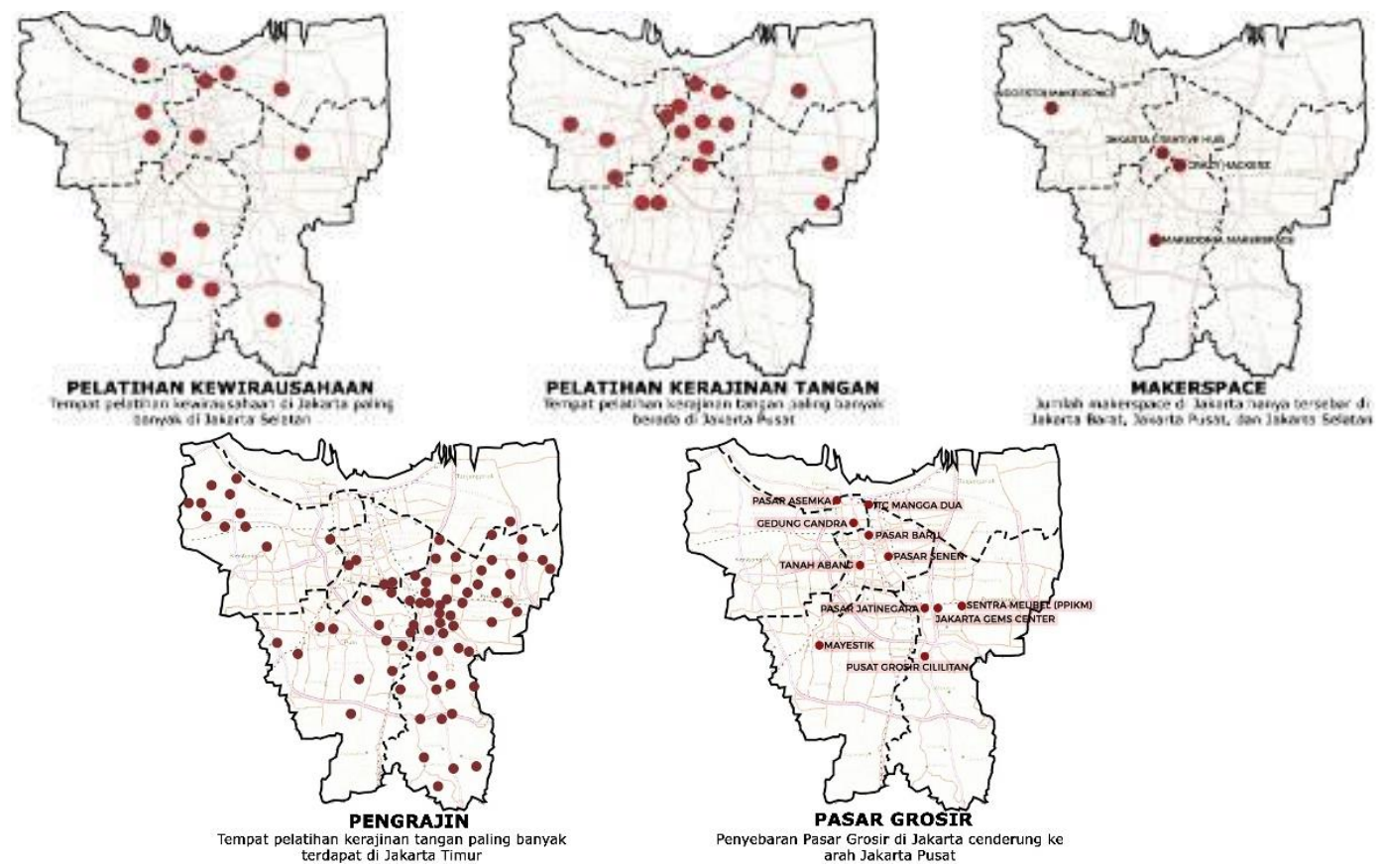

Gambar 2. Analisa Makro Kawasan

Sumber: Penulis, 2019

Analisa Makro Kawasan dilakukan dengan tujuan untuk mengetahui daerah Jakarta mana yang paling sesuai dengan kriteria tapak pembangunan proyek ini, antara lain:

- Terletak dekat dengan fasilitas pendidikan

- Terletak dekat dengan fasilitas komersial

- Jauh dari tempat pelatihan non-formal (agar tidak bersaing)

Pemilihan tapak untuk proyek ini berlokasi di Jatinegara, Jakarta Timur. Pemilihan tapak di daerah Jakarta Timur dikarenakan adanya konsep everyday urbanism, dimana konsep ini 
mengajarkan untuk mencari kegiatan sehari-hari pada suatu kawasan. Dari pencarian ini muncul data mengenai lima mata pencaharian terbesar di Jakarta Timur, yang tiga diantaranya cocok dengan proyek ini, antara lain: Industri Pengolahan (30,36\%), Perdagangan (19,96\%), dan Jasa Pendidikan (7,40\%).

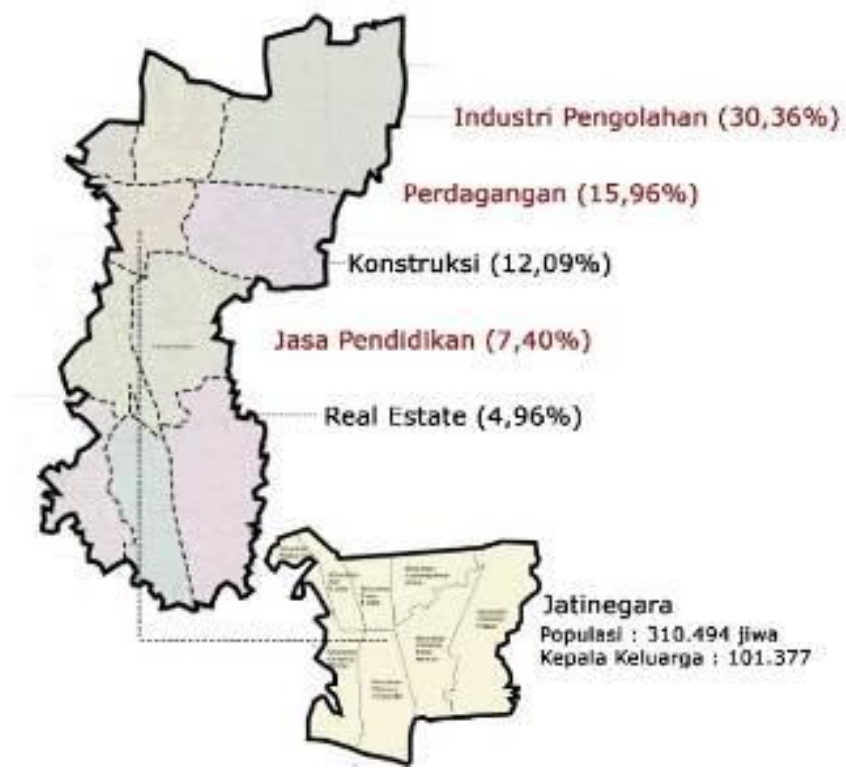

Gambar 3. Mata Pencaharian Terbesar di Jakarta Timur Sumber: Penulis, 2019

Selain itu, dipilhnya Jatinegara sebagai lokasi proyek disebabkan oleh berbagai faktor, salah satunya adalah sudah adanya gagasan untuk menjadikan Jatinegara sebagai tempat wisata mebel dan kerajinan, namun sampai saat ini pemerintah daerah belum merespon.
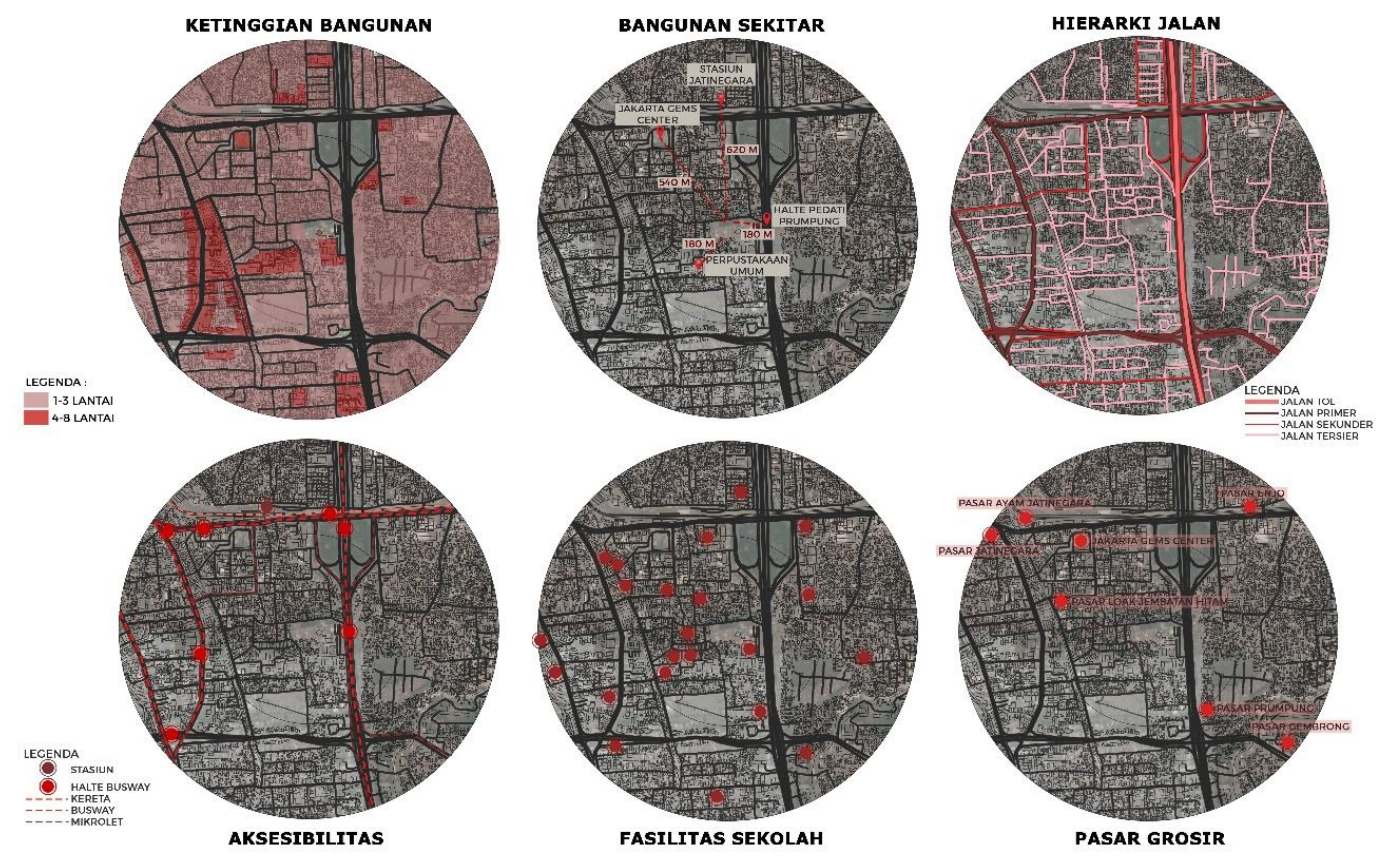

Gambar 4. Analisa Mezzo Kawasan

Sumber: Penulis, 2019

Dari analisa mezzo kawasan diatas, didapatkan bahwa tapak tergolong cukup berpotensi sebagai tempat komersial walaupun berada di second layer kawasan. Hal ini dikarenakan banyaknya pasar grosir, fasilitas sekolah, serta akses transportasi umum yang tidak jauh dengan lokasi tapak. 


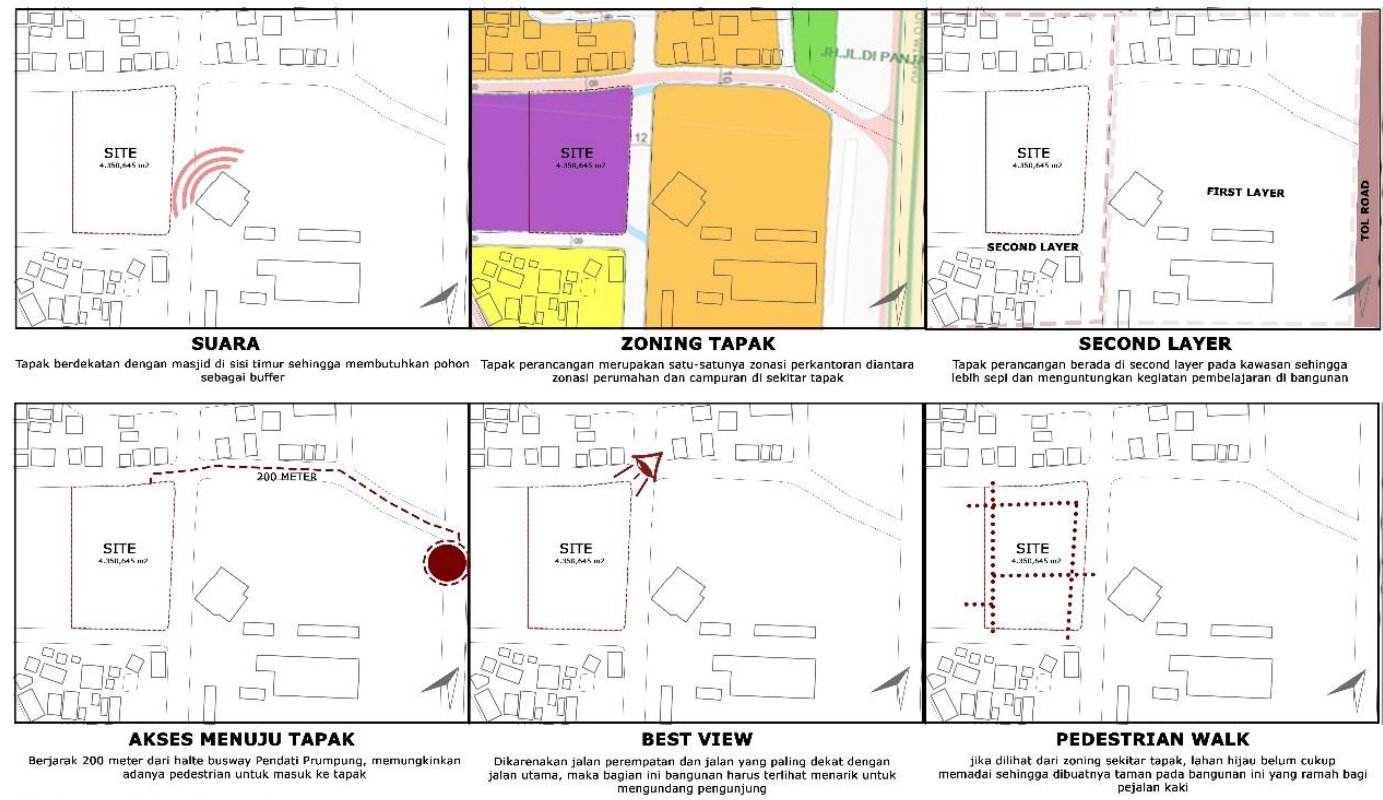

Gambar 5. Analisa Mikro Kawasan

Sumber: Penulis, 2019

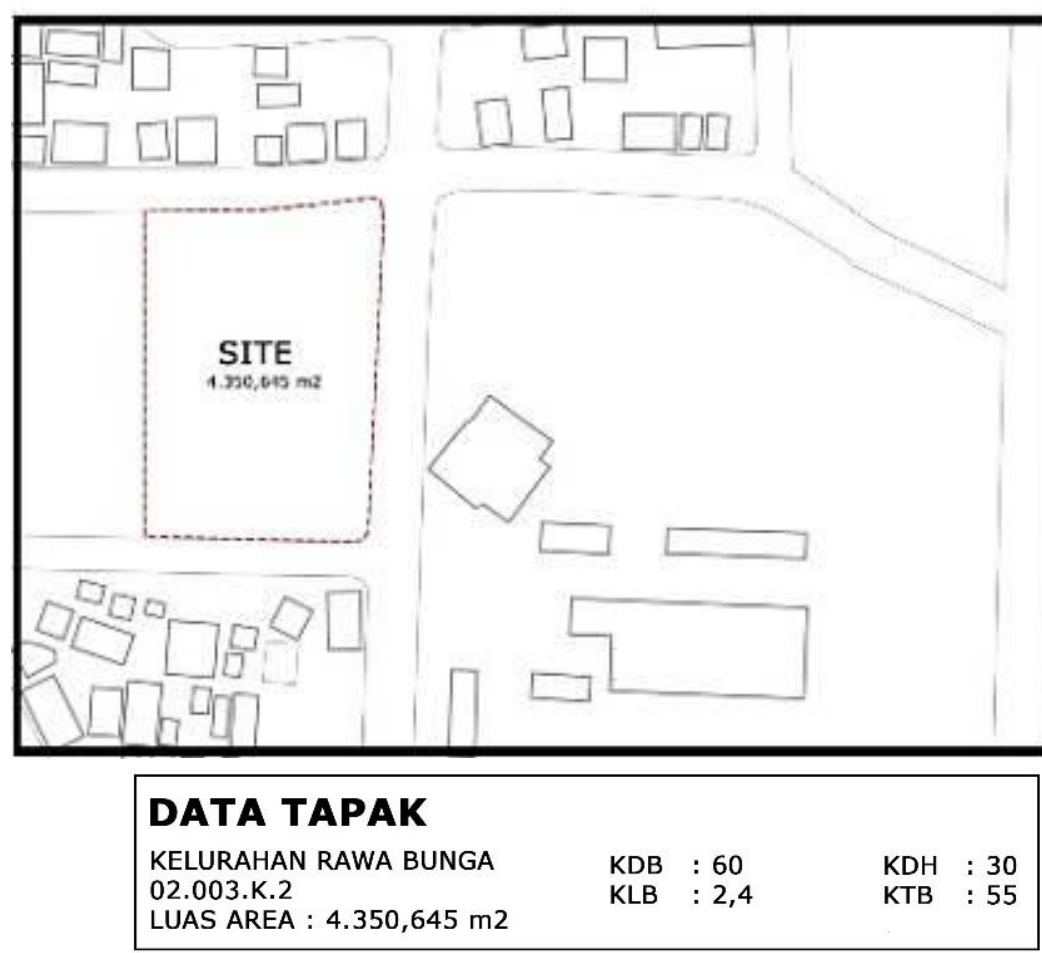

Gambar 6. Data Tapak

Sumber: Penulis, 2019

Berikut adalah analisa mikro dan data tapak dari proyek ini. Dikelilingi oleh perumahan dan zonasi campuran, kawasan ini yang satu-satunya berzonasi perkantoran di daerah sekitarnya berpotensi menjaid bangunan komersial yang dapat menarik banyak pengunjung. Setelah mendapatkan data tapak, tahap selanjutnya adalah dengan membuat programatik proyek. 


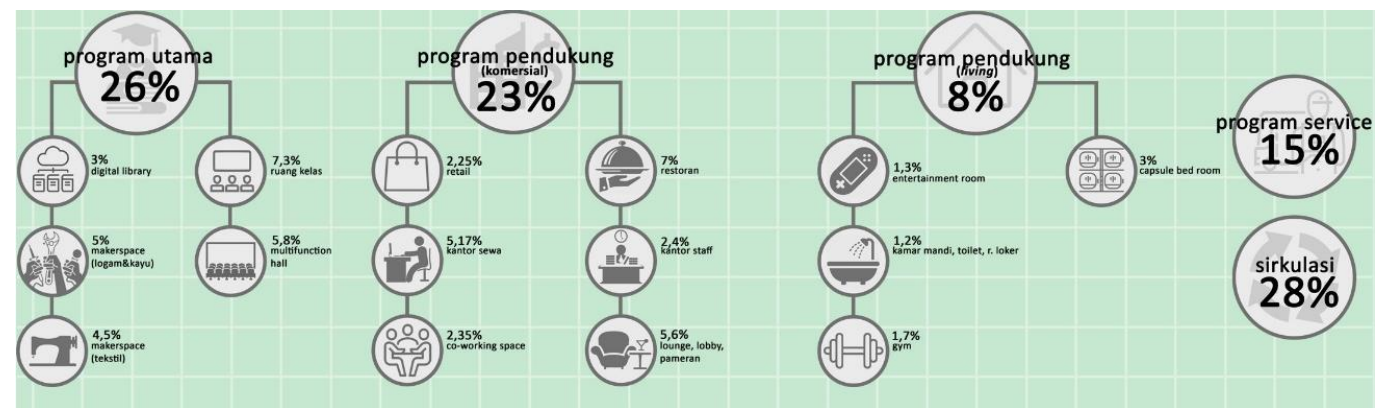

Diagram 3. Program Ruang Proyek Sumber: Penulis, 2019

Diagram diatas menjelaskan programatik proyek yang dimana terdiri dari 1 kategori utama, yaitu pendidikan (26\%), dan dua kategori pendukung, yaitu komersial (23\%) dan kehidupan sehari-hari (8\%). Presentase program lainnya adalah program servis (15\%), dan sirkulasi bangunan (28\%). Setelah mendapatkan programatik proyek, masuklah ke tahap perancangan, yaitu dengan membuat design scheme bangunan.

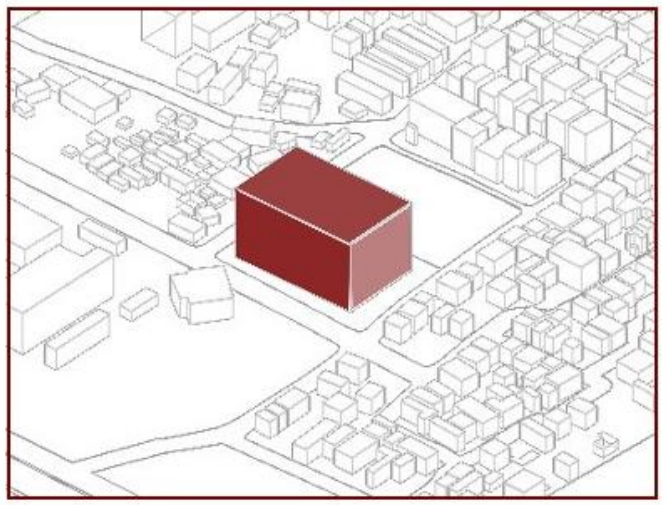

GUBAHAN MASSA AWAL

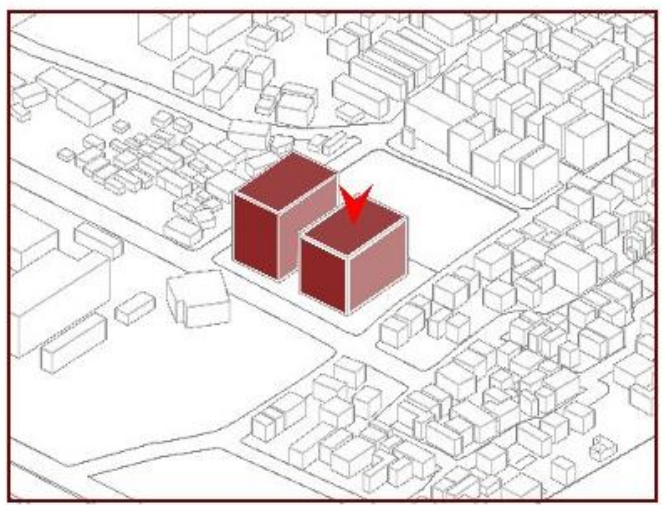

DIFFERENCE HEIGHT

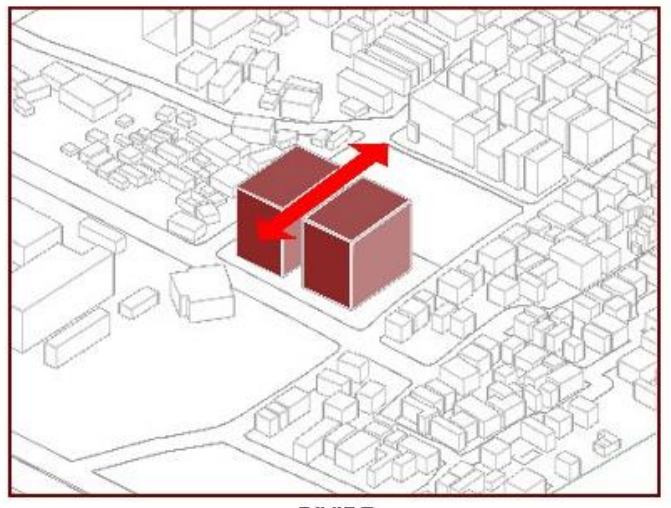

DIVIDE

Dipisah menjadid dua massa, massa pertama bersifal lebir publ < c bagian depar.

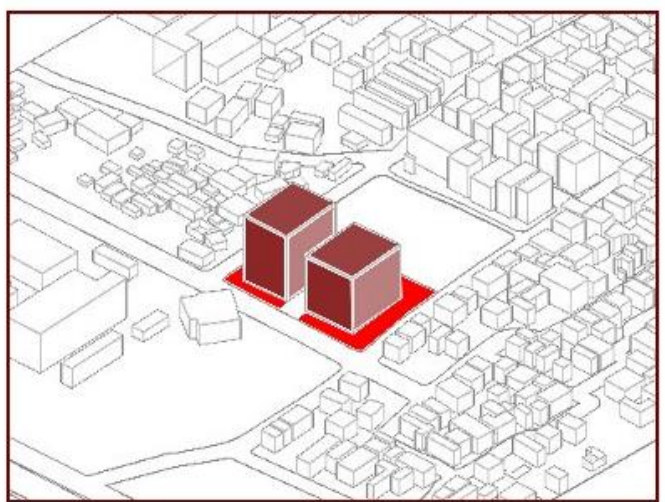

PUBLIC PARK

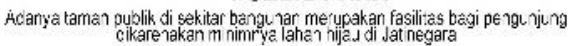




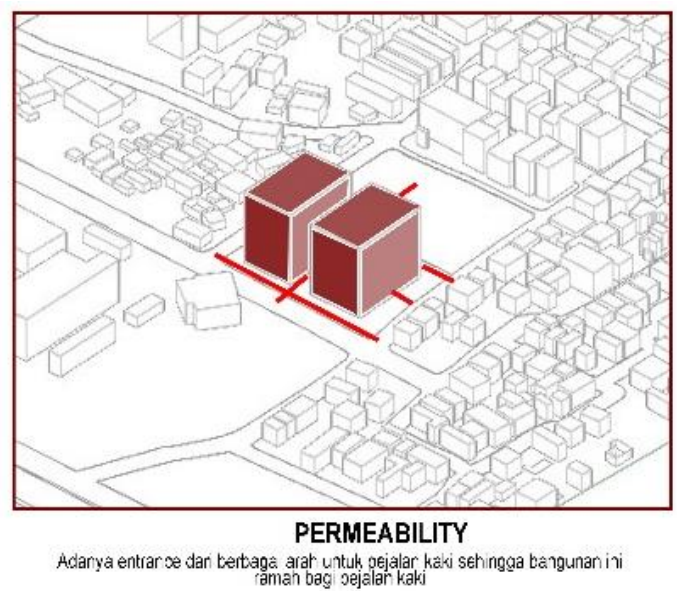

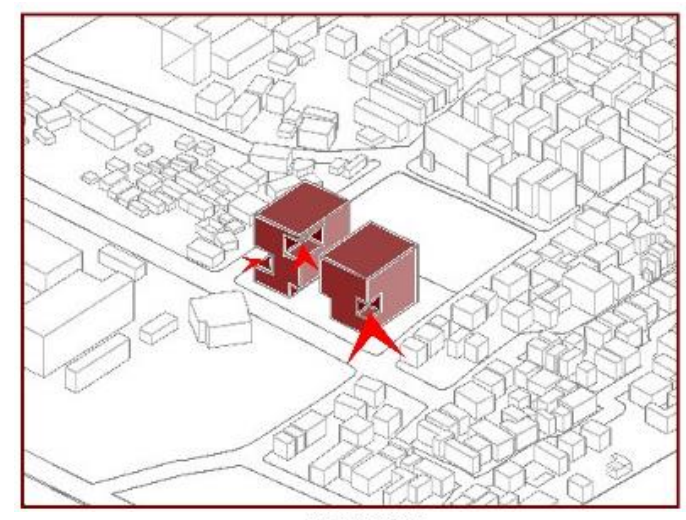

SETBACK

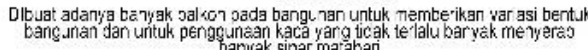

Gambar 7. Design Scheme

Sumber: Penulis, 2019

Konsep utama dari proyek ini adalah untuk membuat sebuah bangunan yang dapat memenuhi semua kebutuhan millennial entrepreneur. Bukan hanya itu saja, dengan konsep permeabilitas dan membuat taman publik di sekitar bangunan bukan hanya dapat menyumbangkan lahan hijau untuk sustainability tetapi juga untuk membuat bangunan menjadi ramai pengunjung, dimana ini merupakan salah satu faktor yang dibutuhkan oleh seorang wirausaha dalam berdagang.

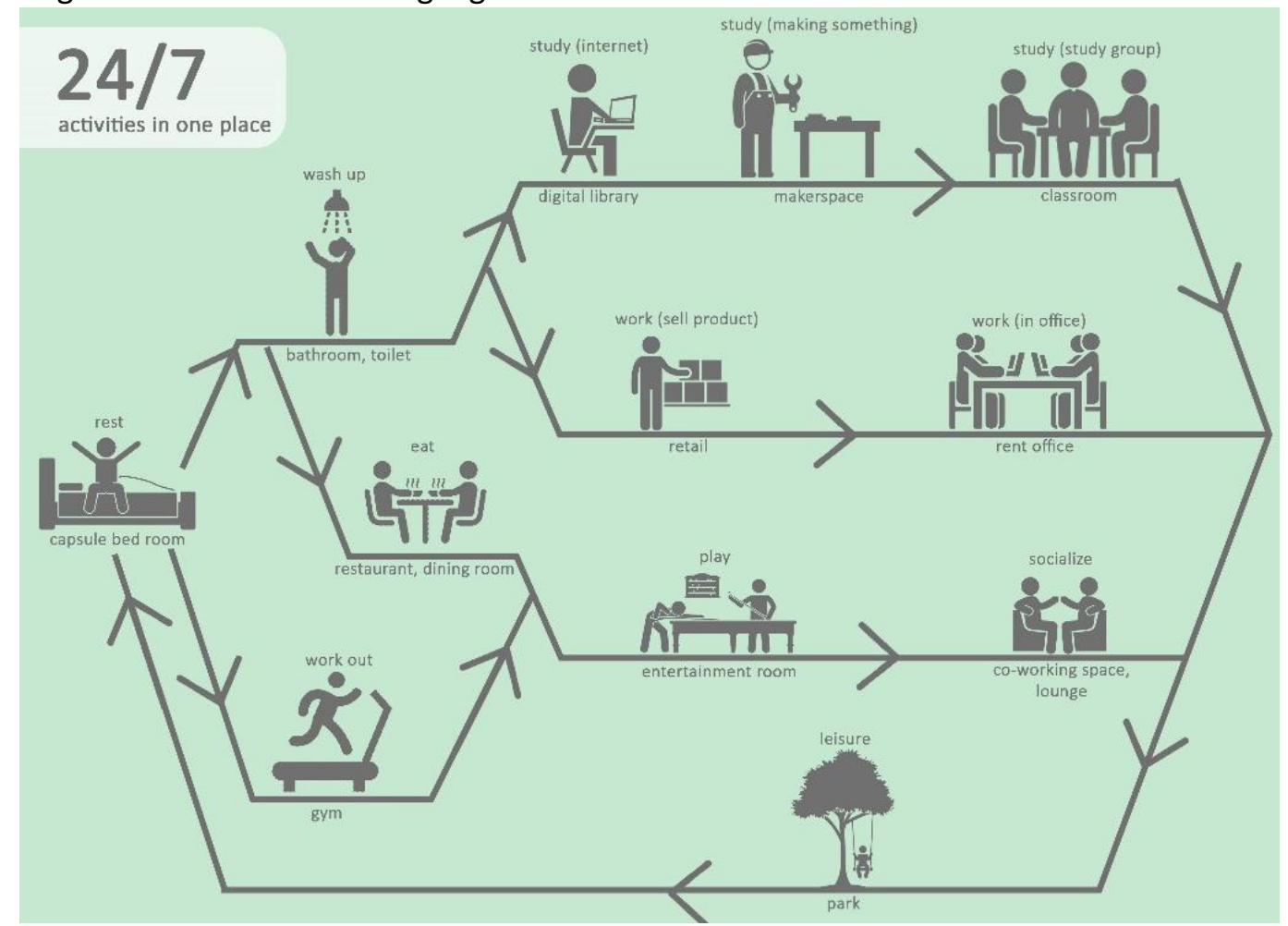

Diagram 4. Skema Aktivitas

Sumber: Penulis, 2019

Diagram di atas menggambarkan seluruh kegiatan millennial entrepreneur dalam satu bangunan. Mulai dari bangun di pagi hari hingga beristirahat di malam hari. 


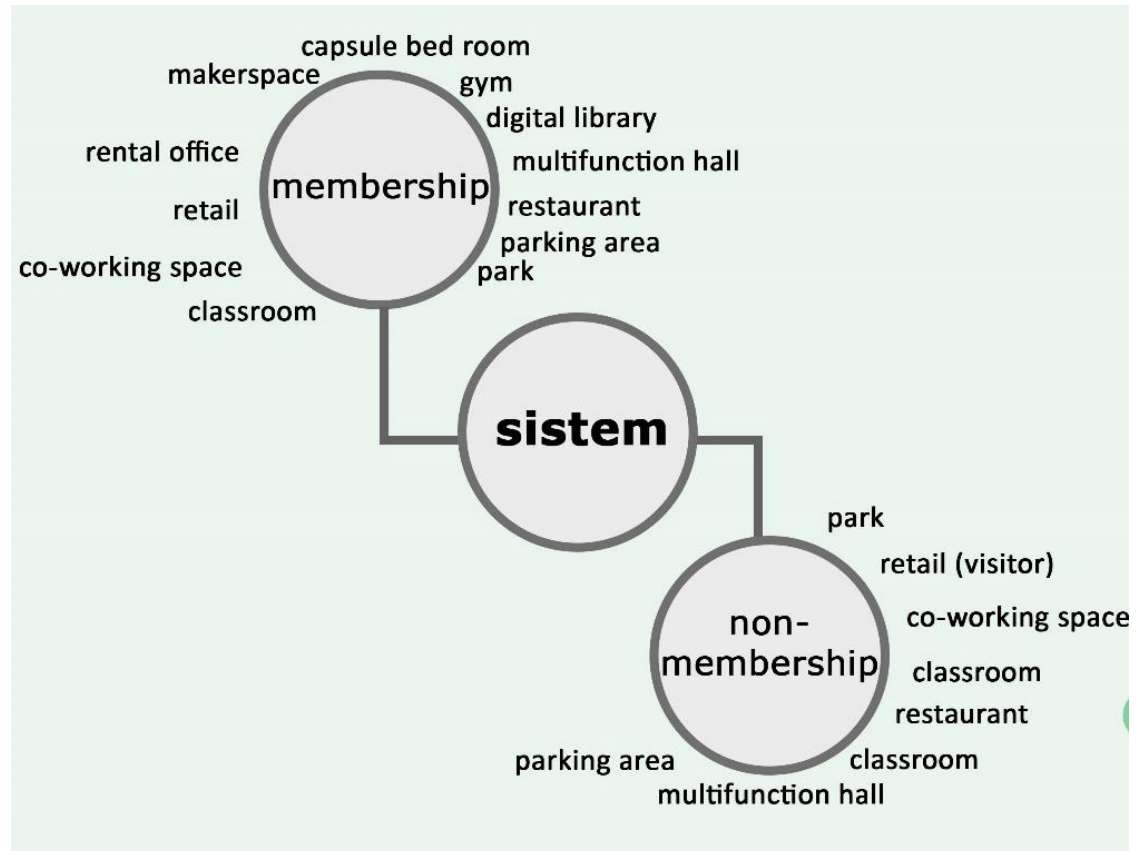

Diagram 5. Sistem Penggunaan Fasilitas Sumber: Penulis, 2019

Diagram ini menggambarkan sistem penggunaan fasilitas pada bangunan ini. Terbagi atas sistem membership dan non-membership, sehingga penggunaan fasilitas bagi yang nonmembership lebih terbatas.

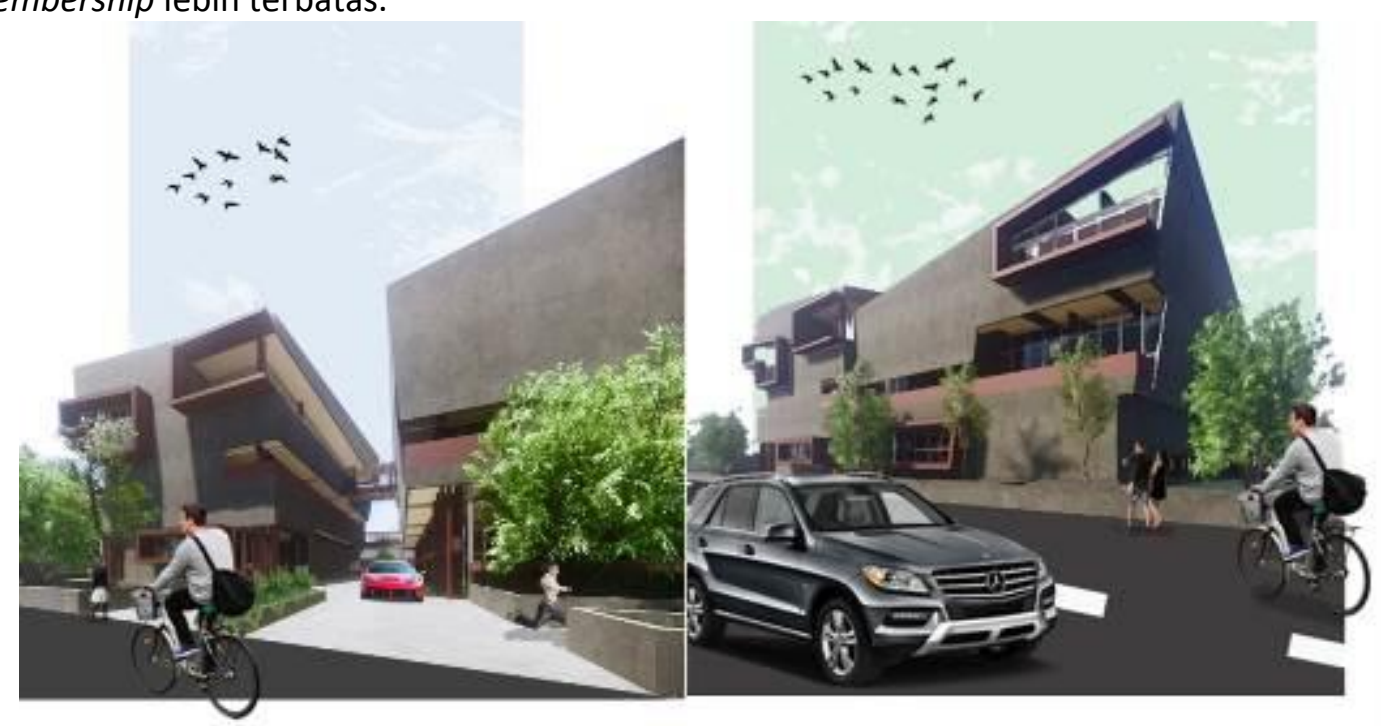

Gambar 8. Perspektif Eksterior

Sumber: Penulis, 2019 


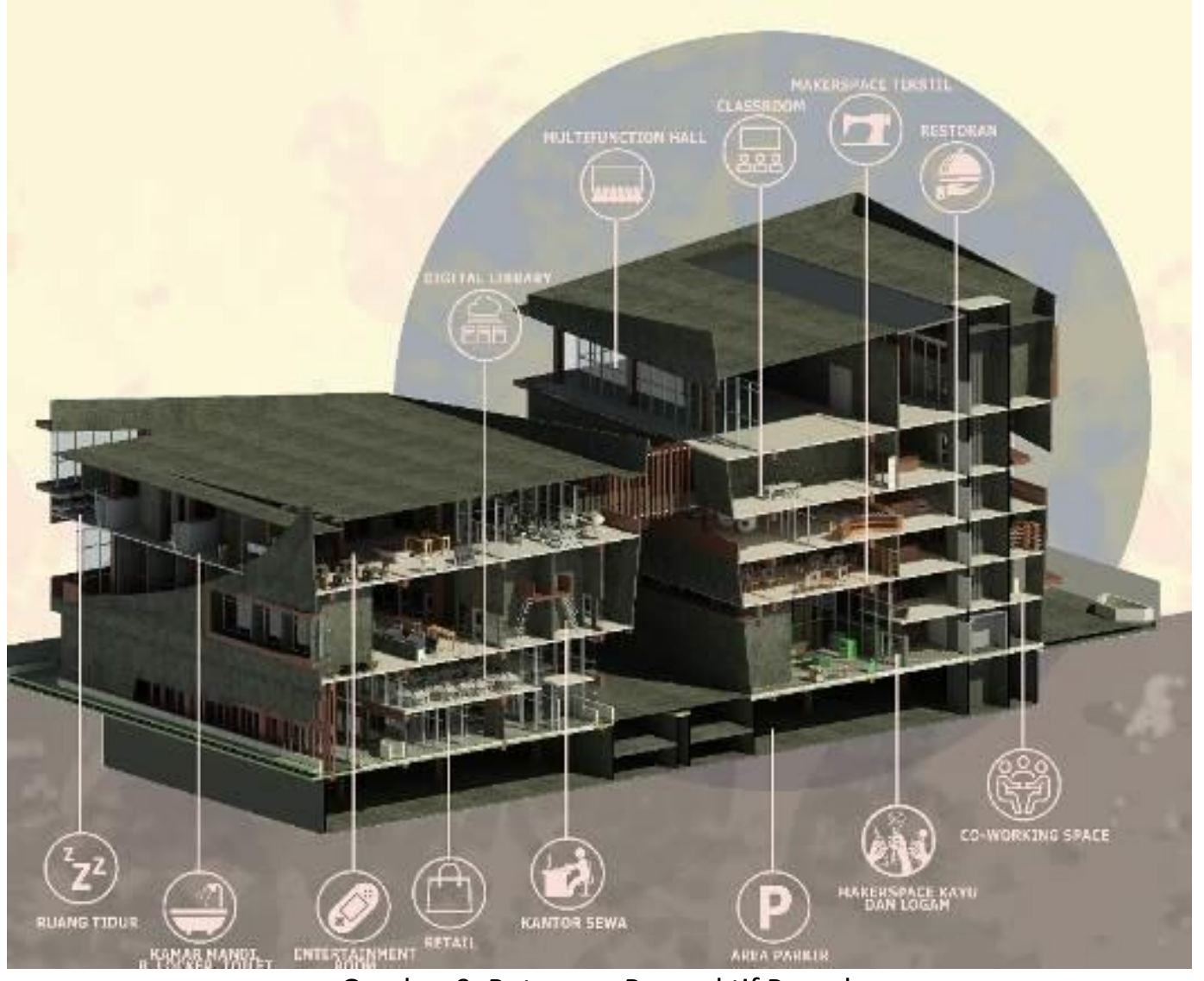

Gambar 9. Potongan Perspektif Proyek

Sumber: Penulis, 2019

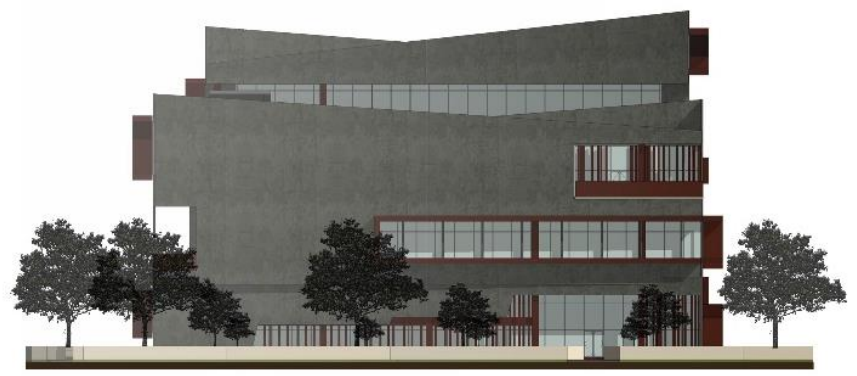

Gambar 10. Tampak Utara

Sumber: Penulis, 2019

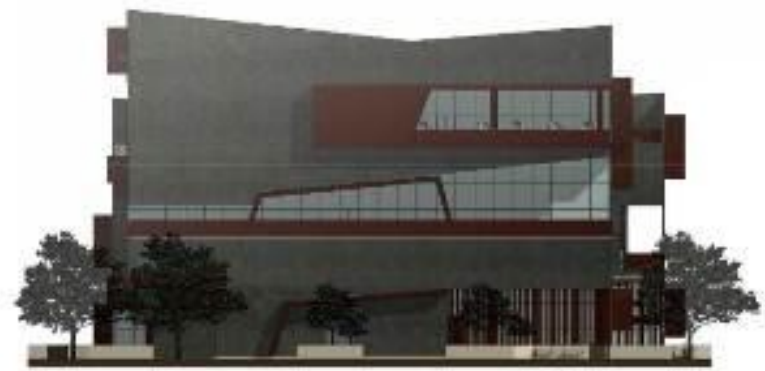

Gambar 11. Tampak Selatan

Sumber: Penulis, 2019 


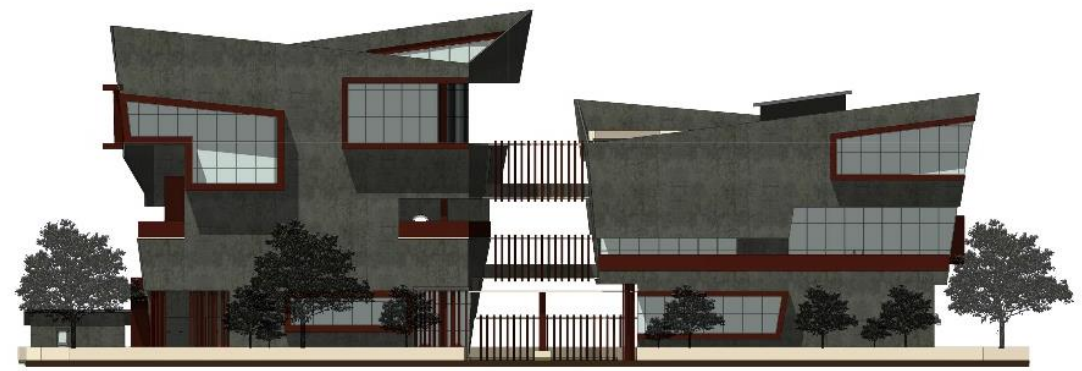

Gambar 12. Tampak Timur

Sumber: Penulis, 2019

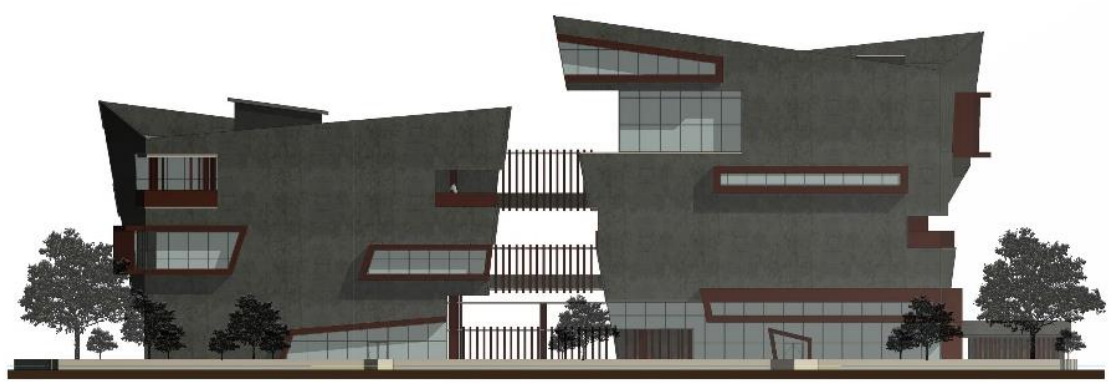

Gambar 13. Tampak Barat

Sumber: Penulis, 2019
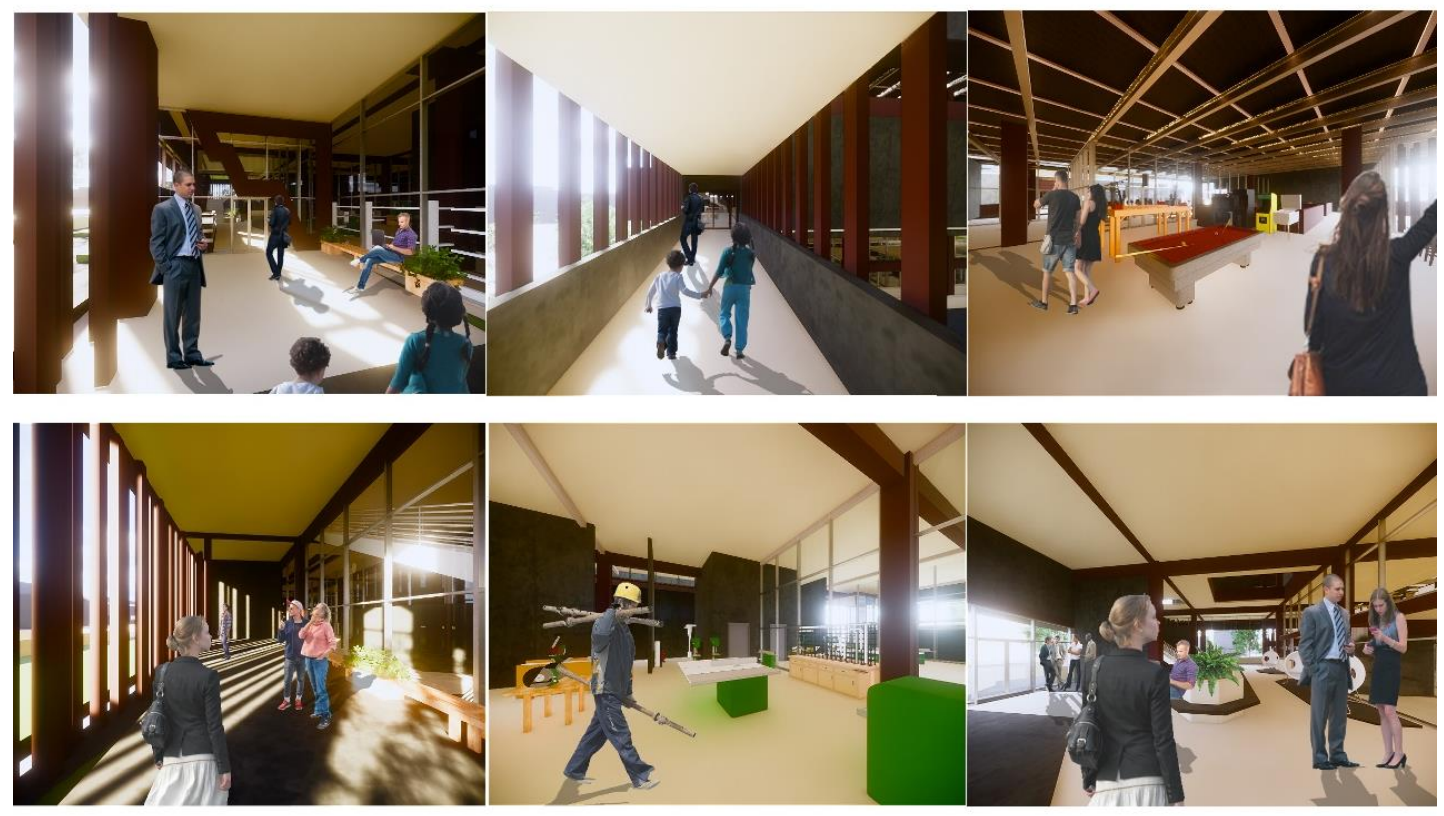

Gambar 14. Perspektif Interior Proyek

Sumber: Penulis, 2019

\section{KESIMPULAN DAN SARAN}

Generasi Milenial membutuhkan adanya wadah untuk mereka dapat mengembangkan kemampuan berwirausaha, namun bukan hanya untuk mengembangkan saja, tetapi juga untuk dapat memenuhi kebutuhan sehari-hari mereka. Sehingga dengan adanya Komunitas Kriya Jatinegara jumlah masyarakat yang tertarik untuk berwirausaha meningkat dan tingkat wirausaha di Indonesia juga semakin meningkat. Konsep dari mixed-use building ini adalah untuk memenuhi semua kegiatan wirausaha, khususnya generasi milenial, dari mulai bangun 
di pagi hari hingga tidur di malam hari. Untuk merancang proyek seperti ini perlu memperhatikan beberapa hal, antara lain sirkulasi servis, kapasitas ruang berdasarkan jenis yang berbeda-beda, dan pencahayaan pada bagian kamar tidur. Hal tersebut dapat mempengaruhi keefektivitasan, kenyamanan, dan juga suasana ruang.

\section{REFERENSI}

Agribisnis. (2019). Industri Kreatif. Retrieved January 16, 2019, from https://agribisnis.co.id/industri-kreatif/

Batukarinfo. (2015). Daya Saing Terkait Nilai Tambah Paling Banyak. Retrieved January 21, 2019, from https://www.batukarinfo.com/news/daya-saing-terkait-nilai-tambah-palingbanyak

Bozzonetti, C. (2017). The Culture in Fabrication:Open Source Tool to Inspire a Maker Community. University of Witwatersrand.

Forbes: (2017). 5 Workspace Changes That Make Millennials Happy. Retrieved February 16, 2019, from https://www.forbes.com/sites/sarahlandrum/2017/10/12/5-workspacechanges-that-make-millennials-happy/\#5c7ec38a743aFrench Dunbar, Meghan: (2015). Seven Fascinating Facts about Millennials. Retrieved January 20, 2019, from https://consciouscompanymedia.com/the-new-economy/seven-fascinating-facts-aboutmillennials/

Kompas. (2017). Skenario Pertumbuhan Ekonomi Tinggi Butuh Kekuatan Wirausaha Muda. Retrieved March 14, 2019, from https://edukasi.kompas.com/read/2017/11/07/15040381/skenario-pertumbuhanekonomi-tinggi-butuh-kekuatan-wirausaha-muda

Makerspaces. (2015). What is a Makerspace?. Retrieved January 19, 2019, from https://www.makerspaces.com/what-is-a-makerspace/

Midmomakerlabs. (2018). Brief History of Makerspaces. Retrieved January 21, 2019, from https://midmomakerlabs.com/brief-history-of-makerspaces/

Pew Research Center. (2015). Millennials On Track to be the Most Educated Generation to Date. Retrieved January 18, 2019, from http://www.pewresearch.org/facttank/2018/03/16/how-millennials-compare-with-their-grandparents/ft_millennialseducation_031715/

Stover\&Associates, J. (2017). Innovation Space \& Marketplace Report: Developing a Makerspace in the District. JS\&A Economic Development Consulting.

Tribunnews. (2018). Cetak 5 Juta Pengusaha Millenial Baru, 2024 Indonesia. Retrieved January 16, 2019, from http://www.tribunnews.com/tribunners/2018/10/09/cetak-5-jutapengusaha-millenial-baru-2024-indonesia-zero-poverty

Wartakota. (2017). Jatinegara Kaum Berpotensi Jadi Wisata Belanja Mebel, Ini Buktinya. Retrieved February 14, 2019, from http://wartakota.tribunnews.com/2017/01/11/jatinegara-kaum-berpotensi-jadi-wisatabelanja-mebel-ini-butkinya 